\title{
Optima of Trypsin-Catalyzed Hydrolysis and Its Inhibition Determined by SDS-PAGE
}

\author{
Xueke Zhou, Tingting Wang, Anjun Wang, Renqiang $\mathrm{Li}^{*}$ \\ Department of Biotechnology, Jinan University, Guangzhou, China \\ Email: *trqli@jnu.edu.cn
}

Received 11 January 2016; accepted 1 March 2016; published 4 March 2016

Copyright (C) 2016 by authors and Scientific Research Publishing Inc.

This work is licensed under the Creative Commons Attribution International License (CC BY). http://creativecommons.org/licenses/by/4.0/

c) (i) Open Access

\begin{abstract}
SDS-PAGE was applied to determine trypsin activity and inhibition. After the hydrolysis by trypsin to substrate bovine serum albulnin (BSA) under different temperatures and $\mathrm{pH}$, the hydrolysis degree of BSA was conducted using SDS-PAGE. From the quantitative analysis to the electrophoresis bands of BSA and its hydrolysis products in SDS-PAGE pattern, the change of trypsin activity was determined, and then the optimum temperature at $40^{\circ} \mathrm{C}$ and the optimum $\mathrm{pH}$ at $\mathrm{pH} 8.5-8.7$ for trypsin activity were obtained. All the target bonds in BSA molecule could be hydrolyzed at the same time by trypsin. The inhibition was due to the binding of inhibitor to trypsin, which made it impossible for trypsin to touch the substrate protein. SDS-PAGE was demonstrated to be also an effect method for assaying the characteristics of trypsin activity and its inhibition.
\end{abstract}

\section{Keywords}

Trypsin-Catalyzed Hydrolysis, Trypsin Inhibitor, Optimum Condition, SDS-PAGE, Assay Method

\section{Introduction}

As a protease produced mainly in animals, trypsin is an important digestive enzyme. So far trypsin is diffusely applied to industry, agriculture, ecology and medicine and has been studied widely [1]. The most common laboratory methods to determine enzyme activity, kinetics and inhibition are spectrophotometric and fluorometric assays [2]. The natural substrates of trypsin are proteins that can be hydrolyzed into peptides, which is inconvenient for assaying trypsin activity due to no change of absorption light appear for the peptides. So N-benzoyl arginine ethyl ester (BAEE) that is a nonprotein substrate mimic for trypsin and the hydrolysis of which can be observed through a change in absorbance is in common used for assaying trypsin activity [3] [4]. Almost all of the methods for protease study based on the spectroscopy require labelling of substrates with the chromophore

"Corresponding author. 
or fluorophore groups. However, many assays employing BAEE demonstrate that the activity of trypsin is influenced, suppressed or enhanced in mixed aqueous-organic solvent systems [5]. In our practice, unstable results for trypsin activity assay employing BAEE also appeared. In fact, it is difficult to truly reflect the actuality by using the nonprotein substrate mimic or protein substrate conjugated the chromophore or fluorophore groups for studying trypsin functional characteristics due to the real substrates of trypsin are proteins.

Recently, a physical technique, isothermal titration calorimetry (ITC) for determine the kinetics of trypsincatalyzed hydrolysis was used [6], in which the substrate for trypsin was real substrate protein. In this study, after the trypsin-catalyzed hydrolysis with the protein as substrate of trypsin, SDS-PAGE was applied to conduct the changes of protein substrate because the polyacrylamide gels were effective tool for detection of proteins [7] [8]. Bovine serum albumin (BSA) were used as the substrate, the optima of trypsin-catalyzed hydrolysis and its inhibition were detected through SDS-PAGE with image scanning and quantitative analysis of the products of enzymatic reaction. A novel method for trypsin assay was demonstrated, which is of significance for protease activity assay due to the natural substrate of protease is protein.

\section{Materials and Methods}

\subsection{Materials}

Trypsin, trypsin inhibitor (21 KD) purified from soybean and BSA was from Sigma. All other chemicals used in SDS-PAGE or for buffers were of analytical or chemical grade and were purchased from Guangzhou Chemical Co. Ltd. (Guangzhou, China). Markers for SDS-PAGE were supplied by Shanghai Sheng Zheng Biotechnology Co. Ltd. (Shanghai, China).

\subsection{Enzymatic Reactions with Different Temperatures}

Based on the preliminary test, BSA was directly dissolved in deionized water to make a $5 \mathrm{mg} / \mathrm{mL}$ solution and the concentration of trypsin dissolved in $5 \mathrm{mmol} / \mathrm{L} \mathrm{HCl}$ was $0.625 \mathrm{mg} / \mathrm{mL}$. EP tube with $0.2 \mathrm{~mL}$ trypsin was placed in preheated water for 5 minutes and then $0.4 \mathrm{~mL}$ BSA was added to the tube for the reaction of $10 \mathrm{mi}-$ nutes. In this condition, as the substrate of enzymatic reaction, BSA was enough to be hydrolyzed by trypsin. The enzymatic reaction was terminated by put the reaction tube in boiling water. Five temperatures, $20^{\circ} \mathrm{C}, 30^{\circ} \mathrm{C}$, $40^{\circ} \mathrm{C}, 50^{\circ} \mathrm{C}, 60^{\circ} \mathrm{C}$ were adopted respectively in these tests [9] [10]. Every experiment was repeated three times.

\subsection{Enzymatic Reactions with Different $\mathrm{pH}$}

Tris-HCl buffer of $0.2 \mathrm{~mol} / \mathrm{L}$ was respectively made in different $\mathrm{pH}, 0.2 \mathrm{~mL}$ of which was mixed with $0.2 \mathrm{~mL}$ of trypsin in EP tube. The reaction tube was placed in $40^{\circ} \mathrm{C}$ water for 5 minutes and then $0.4 \mathrm{~mL}$ BSA was added to the tube for the hydrolysis of 10 minutes. The enzymatic reaction was terminated by put the reaction tube in boiling water.

\subsection{Enzymatic Reactions with Inhibitor}

Inhibitor was directly dissolved in deionized water to make a $1 \mathrm{mg} / \mathrm{mL}$ solution. The inhibitor solution of 0,20 , $40,60,80,100 \mu \mathrm{L}$ was respectively mixed with $0.2 \mathrm{~mL}$ trypsin, and then the deionized water of $100,80,60,40$, 20, 0 also be respectively added in the EP tube to ensure the same condition of the reaction system. The reaction tubes were placed in $40^{\circ} \mathrm{C}$ water for 5 minutes and then $0.4 \mathrm{~mL}$ BSA were added to the tubes for the reaction of 10 minutes. The enzymatic reaction was terminated by put the reaction tube in boiling water.

\subsection{SDS-PAGE and Their Analyses}

After the stopping of trypsin-catalyzed hydrolysis by using boiling water for every sample, the protein solutions in certain amount (same amount for an experiment) were mixed with 1\% SDS-mercaptoethanol solution as the SDS-PAGE samples. Gel concentration used in SDS-PAGE was 15\% and the Coomassie was as the stained solution [11] [12]. Scanning of SDS-PAGE pattern was performed using Azure biosystem C200.

Quantity One 4.4 image analysis software from Bio-Rad is a 1D gel quantification software. The software mainly used for gel for dish fluorescence quantitative analysis. There are four main functions: swimming road/ stripe track quantitative method, contour direct quantification, colony counting and molecular weight determina- 
tion [13] [14]. The pictures which got from Azure biosystems C200 were analyzed by the software. Quantitative analysis of any selected region in SDS-PAGE pattern may be performed. The relative concentration can be obtained by the quantitative analysis.

\section{Results and Discussion}

\subsection{Optimum Temperature of Trypsin-Catalyzed Hydrolysis}

BSA is a protein containing some lysine and arginine [15] [16], so it would be hydrolyzed by trypsin into smaller peptides as showed in Figure 1(a). With the different temperatures, the hydrolysis degree for BSA appeared some difference. Comparing to the others, the most retention of BSA was at $60^{\circ} \mathrm{C}$ in Figure 1(a), which was also demonstrated by the quantitative 1D SDS-PAGE analyses to the pattern as showed in Figure 1(b). The amount of product 2 and product 3 at $60^{\circ} \mathrm{C}$ were less than at the other temperatures, which explained that the hydrolysis degree from BSA and the product 1 were weaker, or the optimum temperature for trypsin activity was not at $60^{\circ} \mathrm{C}$, maybe trypsin had higher activity at $60^{\circ} \mathrm{C}$ but was very unstable and lost activity very soon. The hydrolysis degree of BSA at $20^{\circ} \mathrm{C}, 30^{\circ} \mathrm{C}, 40^{\circ} \mathrm{C}$ and $50^{\circ} \mathrm{C}$ had a less difference. But at $50^{\circ} \mathrm{C}$, the retention of product 1 and 2 was more than at the others, and more, the product 3 formed from BSA, product 1 and 2 was less, which explained that the enzymatic activity was weaker during the reaction comparing to at the other temperatures, $50^{\circ} \mathrm{C}$ was not the optimum temperature for trypsin activity. Almost no difference appeared among $20^{\circ} \mathrm{C}, 30^{\circ} \mathrm{C}$ and $40^{\circ} \mathrm{C}$ for trypsin activity in this experiment condition (only reaction for $10 \mathrm{~min}$ ). According to the relationship between temperature and enzymatic activity, $40^{\circ} \mathrm{C}$ could be considered as the optimum temperature for trypsin activity.

The enzymatic reactions lasted only ten minutes in this experiment, so BSA has not been hydrolyzed completely. The intermediate product1 closed to BSA in SDS-PAGE pattern was an important indicator for representing the activity of trypsin. At $60^{\circ} \mathrm{C}$, the retention of product 1 was the most (Figure 1 ), and at $50^{\circ} \mathrm{C}$, the retention of this polypeptide obviously became less, which explained the significant difference for trypsin activity at these two temperatures. But this polypeptide also remained more than at $20^{\circ} \mathrm{C}-40^{\circ} \mathrm{C}$, which further explained the optimum temperature was not at $50^{\circ} \mathrm{C}$.

Therefore, among five temperatures, the most suitable one for trypsin activity was at $40^{\circ} \mathrm{C}$.

\subsection{Optimum pH of Trypsin-Catalyzed Hydrolysis}

The experiment for assaying the optimum $\mathrm{pH}$ of trypsin-catalyzed hydrolysis was conducted at $40^{\circ} \mathrm{C}$ based on the previous tests. The results were showed in Figure 2. Obviously, at pH 7.3 and 7.6 (lane 1 and lane 2 in Figure 2(a)), the trypsin were not in the suitable $\mathrm{pH}$ environment due to the hydrolysis of BSA were weaker than at

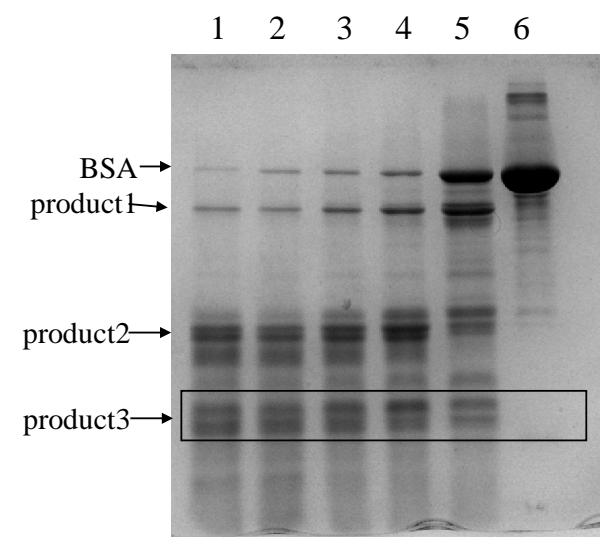

(a)

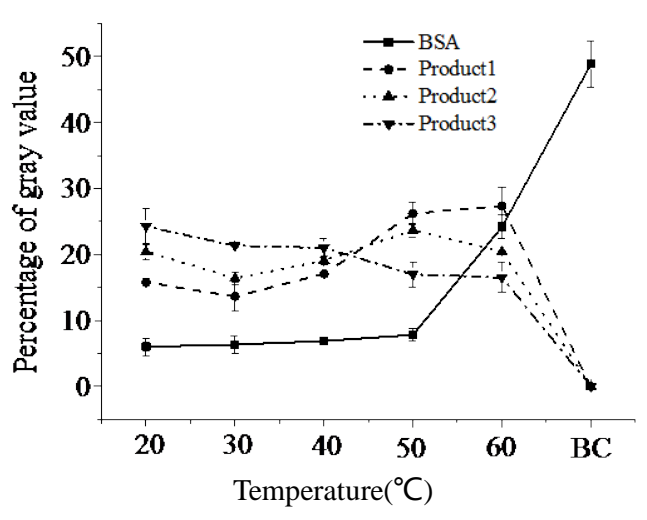

(b)

Figure 1. SDS-PAGE analysis of BSA hydrolyzed by trypsin under different temperatures (a) and their quantitative comparison (b). (a): Lane $1,20^{\circ} \mathrm{C}$; lane $2,30^{\circ} \mathrm{C}$; lane $3,40^{\circ} \mathrm{C}$; lane $4,50^{\circ} \mathrm{C}$; lane 5 , $60^{\circ} \mathrm{C}$; lane 6 , BSA without hydrolysis by trypsin. (b): Solid line, BSA; dash line, product 1 ; dot line, product 2; dash dot line. 
the other $\mathrm{pH}$, also at $\mathrm{pH} 8.1$ (lane 3 in Figure 2(a)). From the quantitative 1D SDS-PAGE analyses as showed in Figure 2(b), the retention of BSA and product 1 that were the main indicator of hydrolysis degree were more at $\mathrm{pH} 8.3$ and 9.1 than at $\mathrm{pH} 8.5$ and 8.7 .

Therefore, the optimum $\mathrm{pH}$ of trypsin-catalyzed hydrolysis was at $\mathrm{pH} 8.5$ and $\mathrm{pH}$ 8.7.

\subsection{Function by Inhibitor}

In this experiment, the volume ratio of the inhibitor to the enzyme was gradually increased with $0,1 / 10,1 / 5$, 3/10, 2/5 and 1/2 to conduct the function of inhibitor. Results were showed in Figure 3, which explained clearly that the suppression of inhibitor to trypsin-catalyzed hydrolysis became larger as the volume ratio of the inhibitor to the enzyme increased because the hydrolysis of BSA was weaker, but the formation of the small polypeptides as product 2 and 3 trended to become less as the volume ratio of the inhibitor to the enzyme increased.

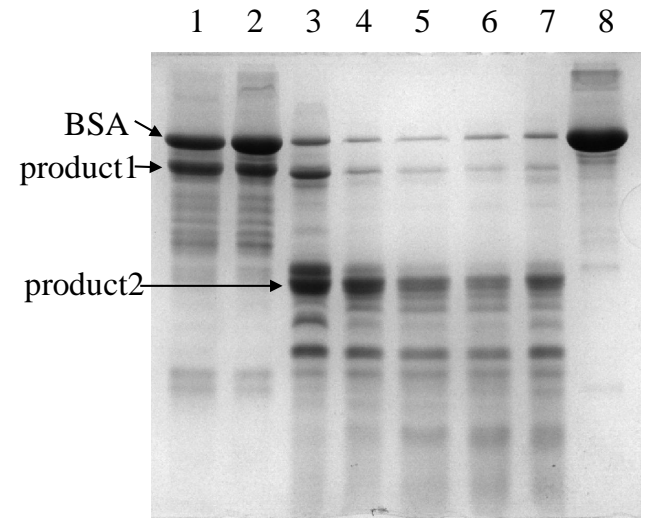

(a)

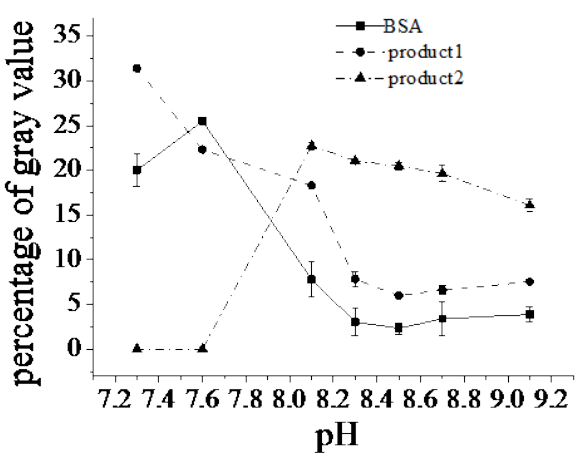

(b)

Figure 2. SDS-PAGE analysis of BSA hydrolyzed by trypsin under different $\mathrm{pH}$ (a) and their quantitative comparison (b). (a) Lane 1, pH 7.3; lane 2, pH 7.6; lane 3, pH 8.1; lane 4, pH 8.3; lane 5, pH 8.5 lane 6, pH 8.7; lane 7, pH 9.1; lane 8, BSA without hydrolysis by trypsin. (b) Solid line, BSA; dash line, product 1 ; dash dot line, product 2. Y-axis (Percentage of gray value) refers to the protein amount of electrophoresis bands.

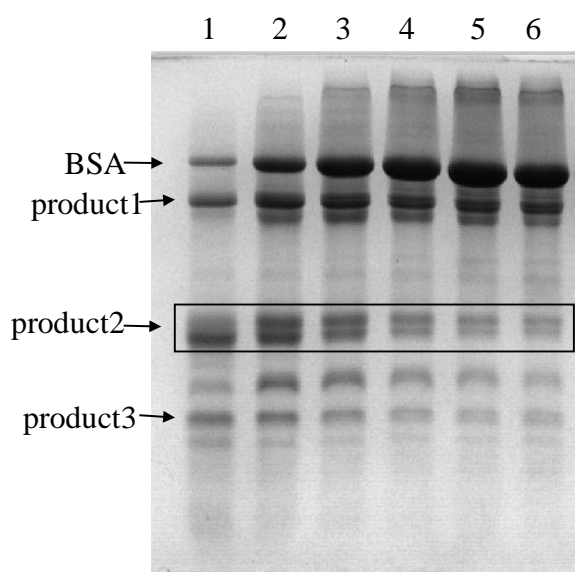

(a)

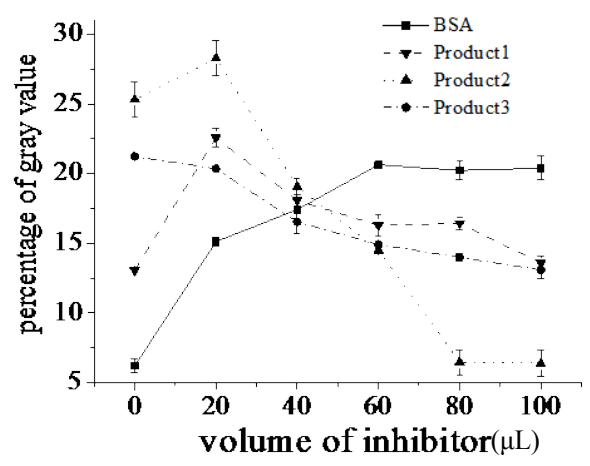

(b)

Figure 3. SDS-PAGE analysis of BSA hydrolyzed by trypsin with the existence of different amount of inhibitor (a) and their quantitative comparison (b). (a) Lane 1, $0 \mu \mathrm{L}$ of inhibitor solution, as a control; lane 2, $20 \mu \mathrm{L}$ of inhibitor solution; lane 3, $40 \mu \mathrm{L}$ of inhibitor solution; lane 4, $60 \mu \mathrm{L}$ of inhibitor solution; lane 5, $80 \mu \mathrm{L}$ of inhibitor solution; lane 6,100 $\mu \mathrm{L}$ of inhibitor solution. (b) Solid line, BSA; dash line, product 1; dot line, product 2; dash dot line, product 3. Y-axis (Percentage of gray value) refers to the protein amount of electrophoresis bands. 
From Figure 3 and the former experiment results, some information about the process of trypsin-catalyzed hydrolysis could be speculated. First, all the peptide bonds that may be functioned by the trypsin in BSA molecule, or the peptide bonds formed by lysine or arginine, could be hydrolyzed at the same time as long as the trypsin was still possessing its activity, which was not related with whether the inhibitor was presented. From the molecular structure, with about $24 \mathrm{KD}$ molecular weight, the trypsin molecule could not swallow all the BSA molecule with about $66 \mathrm{KD}$, the possible reaction process was performed by the active site of trypsin to touch the target bonds in BSA. Therefore, the inhibition of trypsin-catalyzed hydrolysis was speculated to be caused by the binding of inhibitor to trypsin, and the inhibitor (about $21 \mathrm{KD}$ ) was speculated to bind to the active site of the trypsin, which made the enzyme molecule not touch the substrate protein BSA. This inference was consistent with previous studies [17]-[19].

Only those enzyme molecules without the binding with the inhibitor could continue their normal function process, which made the target bonds in BSA be hydrolyzed at the same time as showed in SDS-PAGE pattern.

According to the function process of trypsin inhibitor speculated, the trypsin activity inhibited by the inhibitor was appeared before the reaction of trypsin-catalyzed hydrolysis, was not involved in the actual catalysis process of the trypsin to BSA. Obviously, the inhibitory effect was relied on the combined rate between trypsin and inhibitor. This study explained that the function process of trypsin inhibitor and its inhibitory effect could be determined by SDS-PAGE.

\section{Conclusion}

SDS-PAGE was applied to determine the change of trypsin activity in different condition by conducting the hydrolysis degree of substrate BSA, from which the optimum temperature at $40^{\circ} \mathrm{C}$ and the optimum $\mathrm{pH}$ at $\mathrm{pH} 8.5$ 8.7 were obtained for trypsin activity. The suppression of trypsin activity by the inhibitor was due to the binding of inhibitor to trypsin, which made it impossible for trypsin to touch the substrate protein, only those enzyme molecules without the binding with the inhibitor could continue their normal function process with the target bonds in substrate hydrolyzed at the same time. SDS-PAGE was also an effect method for assaying the characteristics of trypsin activity and its inhibition.

\section{References}

[1] Oliva, M.L.V. and Sampaio, M.U. (2009) Action of Plant Proteinase Inhibitors on Enzymes of Physiopathological Importance. Annals of the Brazilian Academy of Sciences, 81, 615-621. http://dx.doi.org/10.1590/S0001-37652009000300023

[2] Khabibulina, N.V., Vostrilkina, A.V. and Krasnoshtanova, A.A. (2012) Investigating the Effect of Soy Isoflavonoids on the Catalytic Activity of Ribonuclease and Trypsin. Catalysis in Industry, 4, 347-353. http://dx.doi.org/10.1134/S2070050412040095

[3] Sun, Z.J., Xia, S.D., Feng, S.M., Zhang, Z.K., Rahman, M.M., Rajkumar, M. and Jiang, S.G. (2015) Effects of Water Temperature on Survival, Growth, Digestiveenzyme Activities, and Body Composition of the Leopard Coral Grouper Plectropomus leopardus. Fisheries Science, 81, 107-112. http://dx.doi.org/10.1007/s12562-014-0832-9

[4] Gupta, M.N. and Roy, I. (2004) Enzymes in Organic Media Forms, Functions and Applications. European Journal of Biochemistry, 271, 2575-2583. http://dx.doi.org/10.1111/j.1432-1033.2004.04163.x

[5] Crowell, A.M.J., Stewart, E.J., Take, Z.S. and Doucette, A.A. (2013) Critical Assessment of the Spectroscopic Activity Assay for Monitoring Trypsin Activity in Organic-Aqueous Solvent. Analytical Biochemistry, 435, 131-136. http://dx.doi.org/10.1016/j.ab.2012.12.019

[6] Bjerneld, E., Johansson, J., Laurin, Y., Hagner-McWhirter, Å., Rönn, O. and Karlsson, R. (2015) Pre-Labeling of Diverse Protein Samples with a Fixed Amount of Cy5 for Sodium Dodecyl Sulfate-Polyacrylamide Gel Electrophoresis Analysis. Analytical Biochemistry, 484, 51-57. http://dx.doi.org/10.1016/j.ab.2015.04.036

[7] Echan, L.A. and Speicher, D.W. (2002) Protein Detection in Gels Using Fixation. Current Protocols in Protein Science. http://dx.doi.org/10.1002/0471140864.ps1005s29

[8] Liau, C.Y. and Lin, C.S. (2008) A Modified Coomassie Brilliant Blue G 250 Staining Method for the Detection of Chitinase Activity and Molecular Weight after Polyacrylamide Gel Electrophoresis. Journal of bioscience and bioengineering, 106, 111-113. http://dx.doi.org/10.1263/jbb.106.111

[9] Wu, Y.Y., Wang, P., Li, L.H., Yang, X.Q. and Diao, S.Q. (2012) Purification and Characteristics of Serine Protease from the Head of Pacific White Shrimp. Food Science and Biotechnology, 21, 1129-1134.

http://dx.doi.org/10.1007/s10068-012-0147-5 
[10] Sainz, J.C., Garćia-Carreño, F.L. and Hernandez-Cortes, P. (2004) Penaeus Vannamei Isotrypsins: Purification and Characterization. Comparative Biochemistry and Physiology, Part B, 138, 155-162. http://dx.doi.org/10.1016/j.cbpc.2004.03.002

[11] Peterson, G.L. (1979) Review of the Folin Phenol Protein Quantitation Method of Lowry, Rosebrough, Farr and Randall. Analytical Biochemistry, 100, 201-220. http://dx.doi.org/10.1016/0003-2697(79)90222-7

[12] Tenório-Daussat, C.L., Resende, M.C.M., Ziolli, R.L., Hauser-Davis, R.A., Schaumloffel, D. and Saint'Pierre, T.D. (2014) Evaluation and Standardization of Different Purification Procedures for Fish Bile and Liver Metallothionein Quantification by Spectrophotometry and SDS-PAGE Analyses. Talanta, 120, 491-497. http://dx.doi.org/10.1016/j.talanta.2013.11.070

[13] Salvatore, E., Pes, M., Falchi, G., Pagnozzi, D., Furesi, S., Fiori, M., et al. (2014) Effect of Whey Concentration on Protein Recovery in Fresh Ovine Ricotta Cheese. Journal of dairy science, 97, 4686-4694. http://dx.doi.org/10.3168/jds.2013-7762

[14] van Oeffelen, L., Peeters, E., Le Minh, P.N. and Charlier, D. (2014) The "Densitometric Image Analysis Software” and Its Application to Determine Stepwise Equilibrium Constants from Electrophoretic Mobility Shift Assays. PLOS One, 9, 1-8. http://dx.doi.org/10.1371/journal.pone.0085146

[15] Bi, S.Y., Yan, L.L., Pang, B. and Wang, Y. (2012) Investigation of Three Flavonoids Binding to Bovine Serum Albumin Using Molecular Fluorescence Technique. Journal of Luminescence, 132, 132-140. http://dx.doi.org/10.1016/j.jlumin.2011.08.014

[16] Zhao, X.N., Liu, Y., Niu, L.Y. and Zhao, C.P. (2012) Spectroscopic Studies on the Interaction of Bovine Serum Albumin with Surfactants and Apigenin. Spectrochimica Acta Part A: Molecular and Biomolecular Spectroscopy, 94, $357-$ 364. http://dx.doi.org/10.1016/j.saa.2012.02.078

[17] Fumagalli, L., Businaro, R., Nori, S.L., Toesca, A., Pompili, E., Evangelisti, E., et al. (1996) Proteinase Inhibitors in Mouse Skeletal Muscle: Tissue-Associated Components of Serum Inhibitors and Calpastatin. Cellular and Molecular Biology, 42, 535-546.

[18] Bode, W. and Huber, R. (1992) Natural Protein Proteinase Inhibitors and Their Interaction with Proteinases. European Journal of Biochemistry, 204, 433-451. http://dx.doi.org/10.1111/j.1432-1033.1992.tb16654.x

[19] Oliva, M.L.V. and Sampaio, M.U. (2009) Action of plant Proteinase Inhibitorson Enzymes of Physiopathological Importance. Annals of the Brazilian Academy of Sciences, 81, 615-621. http://dx.doi.org/10.1590/S0001-37652009000300023 